\title{
Nationalism Values of Southwest Aceh Society Post Conflict
}

\author{
Rizal Fahmi*, Endang Danial \\ Universitas Pendidikan Indonesia \\ Bandung, Indonesia \\ *rizal29fahmi@gmail.com
}

\begin{abstract}
Indonesia is a multiethnic country and has various kinds of tribe. This diversity will invoke various kinds of problem, one of them is conflict. Conflict will occur if it is not countered by high nationalism spirit in the life of nation and state. The prolonged conflict in Aceh result in the shift of nationalism values, so it reduce unity spirit. It cannot be ignored because it will give negative effect to the life of nation and state. The main problem of this study is to understand and reveal to what extent of Nationalism values of Aceh society post conflict. This study use qualitative approach and make case study as research method and use grand theory Hans Kohn, nationalism is used as analysis tool. The result of this study is the reduction of Nationalism values among Southwest Aceh society Post Conflict so it needs the effort to revitalize Nationalism values in order to maintain the integrity of Unitary State of Republic of Indonesia. It need more attention given by local government and central government to maintain the unity in order that conflict occurred in many regions in Indonesia particularly Aceh not recurred.
\end{abstract}

Keywords—values; nationalism; conflict

\section{INTRODUCTION}

Indonesia is an archipelago country whose society have different character and disposition. That difference can result in various problems, one of them is conflict (social and political). Many conflicts occur in Indonesia such as in Aceh, Ambon, Papua and another region. The conflict is caused by various kinds of problem such as social gap, religious conflict and interethnic conflict.

The prolonged conflict in Aceh particularly Southwest Aceh resulted in traumatic among Aceh people, and another effect felt after the conflict is lack of nationalism among them. Conflict in some regions (Aceh, Papua, Ambon, etc.) caused the lack of nationalism values in society. There are many Aceh people particularly Southwest Aceh people still keep resentment for the conflict crime committed by government. It cannot be ignored, because it will raise new problem in life order of Aceh people particularly in the nation and state life. It need government and community effort to revitalize the nationalism values in order to return back nationalism values of Aceh society.

\section{THEORETICAL}

Values are abstract things and contained in each human. Value are something important and existed in each elements of human life, all activity done by human in daily life always filled by values, both positive and negative. Smith and Schwartz conceptualization is consistent with the sociological view that values are abstract concepts, but not so abstract so they cannot motivate behavior. The classic conception of values in anthropology was introduced by Kluckhohn and Strodtbeck [1]. In this view, values answer basic existential questions, helping to provide meaning in people's lives [2]. In essence, values are the concept contained in sociology, and values also can answer various problems in each human life.

In daily life, values are something worthy, qualified and show quality, and useful for humans [3]. Bilsky and Schwarts, values as concept or belief about expected behavior or condition, which overcome certain situation, become guidance in choosing and evaluating behavior and event and it is ordered based on its relative important meaning [4]. Values which color human life so far, so human life will be more directed. Without values, human life in society will be uncertain, have no direction and goal which want to be achieved.

Values become the most important consideration in each action, and also values become main driving force to do an action. Values as quality of something useful for human life both mental and spiritual [5]. In human life, values are made to become foundation, as rationale to behave consciously or unconsciously. Values are integration of all culture elements which are considered good or bad in a society. Therefore, society require its citizens to inculcate and practice the ideal values $[6,7]$.

Values are cognitive representation of universal human requirement; biological needs, social interactional requirement, and social institutional demands on the individual [8]. The quality of human life whether good or bad is determined by how the values are practiced by that human. Values also are something fundamental for everything done, so value should become driving force for all decisions made [9].

Values should become foundation to be used and as foundation for the effort done when thinking the decision which will be taken. Values as objective thing, which is psychological or material which everyone try to achieve [10]. Values as internal belief used to show that the certain way of behave or the certain way of life is preferable personally and socially compared to another way of behave or life which is contrary [11].

Each action that human do will always contain the values. When we think about values, then we think about the important 
thing for our life such as safety, freedom, wisdom, success, virtue, and pleasure [12]. Values are something contained in human heart which give moral base and principle which are standard of beauty and efficiency or wholeness of conscience [6]. In interacting in social life, human cannot be detached from values, values should be made to become firm foundation in behaving daily in society. Values also should become main guidance in each action which will be done by human.

We use our culturally learned values as standards to determine whether we are as moral and competent as others, to guide our presentations to others, and to help us rationalize beliefs, attitudes and behaviors that would otherwise be personally or socially unacceptable [13]. With values in social life, then it will make life become better so it will create feeling of safety and peaceful. So human does not feel that there is something insufficient, and there is something odd in our daily life, when she/he practice well all values contained in society in his/her all acts.

Conflict is dispute or hostility among individuals or among groups in society because there is certain interest. Conflict is a form of social interaction when two individuals have different interest and losing harmony among one person with another person or one group with another group [14]. Conflict is a fighting, war or physical confrontation with another party [15]. The conflict in Aceh is conflict which occur because of disappointment felt by Aceh people for a long time in the heart of because they feel that Indonesian government put them in detriment. The relation which is less harmonious between Aceh and central government also become problem of profit sharing which very harm Aceh people and make conflict in Aceh become more complicated. The disappointment felt by Aceh people finally realized by the revolts done by Aceh people such as DT/TII and GAM revolts.

Conflict in Aceh is political conflict between Aceh government and central government. Aceh demand central government to self-disintegrate from Unitary State of Republic of Indonesia. It is in accord with the statement "Government conflicts deal with regime type and the composition of the government. In territorial conflicts, the incompatibility concerns the status of a territory and may include demands for secession or autonomy" [16]

The argument above explain that government conflict dealt with governmental regime. In territorial conflict, disagreement regarding status of a region and probably comprise the demand to disintegrate from legitimized state or autonomy. The revolt occur in Aceh finally can be reduced by central government's promise given to Aceh people such as Aceh people are given freedom in education, religion and custom. But in reality, the freedom given to Aceh people regarding education, religion and custom is just a dream promised to central government. This make Aceh people become more disappointed and probably someday this disappointment will be raised if central government still not respond this problem seriously.

Nationalism derived from the words nation from Latin word nation, which is developed from the word nascor (I was born), then initially nation is defined as "group of people born in the same place" [17]. The word 'nationalism' according to Abbe Barruel for the first time is used in German in 15th century, which is addressed to college students who come from same region and same language, so they (in new campus and new region) continuously show their love to their origin nation/tribe [17]. Initially, nationalism related to the love showed by group of people toward their origin nation, language and region. Nowadays, such love is called as patriotism spirit. Thus, initially nationalism and patriotism have same meaning.

Nationalism is a principle in which the highest loyalty of individual should be given to nation and state [18]. Meanwhile, Nugroho Notosusanto emphasize that nationalism is spirit which is alive in human and dedicated for the country's glory [19]. Nationalism is ideology in which member of a nation or nation-state has responsibility to be loyal to nation and aims to manifest life in society [20].

Nationalism is an ideological movement to achieve and defend economic, unity and identity of a population whose members are determined to form actual and potential nation. Smith also give 3 (three) fundamental ideas from nationalism idea as an ideology, among others are [21]:

- Idea about national autonomy, which means that a nation should has whole autonomy, capable to selfregulate, has its own law, independent, free from outside pressure.

- Idea about national unity, which means that it is main foundation in maintaining national unity in nation and state life.

- Idea about national identity, National identity is rooted in unique national character contained in that nation.

In Indonesian context, nationalism which is related to territorial, sovereignty and state had been finished. It means that nationalism which is based on people imagination who has sovereign country had been achieved by embodiment of Unitary State of Republic of Indonesia. Therefore, it can be concluded that nationalism is the feeling of love and proud, natural love toward motherland, recognize and appreciate fully the diversity of Indonesian nation, defend the motherland if it is threaten, always build good relationship and tolerance toward the others, has sense of care, loyal to friend, love peace, sensitive and care about environment, care about social and state problems. Nationalism has characteristic and attitude which should be possessed by citizen. This is in accord with characteristic and attitude of nationalism itself as expressed by Suprapto, proud to be nation and part of Indonesian people, recognize, maintain and develop the country and nation reputation; 2) Always build brotherhood, solidarity and peace among group of community with brotherhood spirit of Indonesia; 3) Aware fully as part of another nation in building cooperation which is mutual beneficial; 4) Love the motherland, Indonesia; and 5) Prioritize collective interest over individual and group interest [22].

Nationalism is 'citizens' loyalty to their nation. Someone has nationalism if he/she recognize and respect the symbols which unite nation, such as: Pancasila, Merah Putih Flag, The National Anthem Indonesia Raya, Burung Garuda Symbol, etc. One topic which is strongly reflect the value of Indonesian nationalism is loving motherland. Loving motherland means 
willing to sacrifice for motherland and defend it from all kinds of threat, challenge, obstacle and disturbance which come from anywhere [23].

Values are everything preferable or desired, idealized and agreed and considered as very important and valuable [24]. Therefore, the values of Indonesian nationalism are the values derived from the spirit of Indonesian nationality which are expected to become behavior standard for Indonesian citizens in the life in society, nation and state.

\section{METHOD}

Study is sequence, means or activity in conducting study which is based on basic assumptions, philosophical and ideological views, questions and issues faced by researcher in finding the truth [25]. Data in this study is verification qualitative which will be casted in the form of essay. The verification qualitative is inductive approach to all research processes which will be conducted.

Qualitative study is methods to explore and understand the meaning which some individuals or people think come from social or human problems. This qualitative study involve important efforts, such as asking questions and procedures, collect specific data from participants, [26]. This study certainly will discuss and describe about revitalization of nationalism values among Southwest Aceh people post conflict. Basically, researcher will search information from people who live in Southwest Aceh about revitalization of nationalism values post conflict.

Sample of data source in qualitative study are selected in purposive and snowball sampling. Purposive is samples who are selected thoroughly by taking up research object selectively and having specific characteristic. Snowball sampling is sampling technique which is done initially in small number initially and then the number is become bigger $[25,26,27]$.

Researcher select the sample needed in accord with the scope of problem which had been designed by researcher in earlier stage. In this case, the sources who understand about the history of conflict in Aceh and the effort done to revitalize nationalism values among Southwest Aceh people post conflict. Subject or participant in this study is selected by using the criteria which is commonly used in qualitative study. There are some criteria used in determining subject of study, namely setting, actors, events, and process [28]. As for the subject of this study will be adjusted with requirement and need in field. The subject of study to obtain data in this study are as follow:

TABLE I. INFORMANT OF THE STUDY

\begin{tabular}{|l|l|l|}
\hline No. & \multicolumn{1}{|c|}{ Informant } & \multicolumn{1}{c|}{ Number } \\
\hline 1. & Public Figure & 20 persons \\
\hline 2. & Traditional Leaders & 10 persons \\
\hline 3. & Academician & 5 persons \\
\hline 4. & LSM & 5 persons \\
\hline
\end{tabular}

In total, subjects who will be taken by researcher as participant in this study are 40 informants. This study is located in Aceh province and will take 1 (one) Regency as location of research namely Southwest Aceh Regency. The reason in selecting this location is because researcher think that Southwest Aceh Regency can represent nationalism values among society in a whole both in urban area and rural area.

\section{RESUlt AND DISCUSSION}

There is lack of nationalism values among Southwest Aceh people after the conflict occur. It is because Aceh people feel injustice. People begin apathetical toward unity in the life of nation and state. In addition, the items of MoU Helsinki which contain the privileges given by central government to Aceh region are not fully realized. It is another factor which cause the lack of nationalism values among Southwest Aceh people.

According to some opinions, that nationalism which had been created for a long time in society life become useless because of people disappointment toward government such as torture, raping and many another war crime done by some people who ever in charged in Southwest Aceh during conflict. However, not all people of Southwest Aceh lack of their nationalism as result of conflict in Aceh. Southwest Aceh government and all elements of society had done the effort to revitalize nationalism values post conflict. That revitalization is done through some ways such as socialization, religious sermon, and activities which can revive nationalism spirit among Southwest Aceh people.

The problem of political conflict in Aceh today is internal problem of Republic of Indonesia because some Aceh people perceive that central government always betray each agreement which had been made [29]. It is initiated from the beginning of the Independence Day even until now. This condition is exacerbated by governmental policy which is considered and believed by Aceh people always put their interest in detriment. Central government always exploit the wealth in Aceh for their interest, but they oppress and intimidate Aceh people.

One agreement which had been betrayed by central government is in 1947 when Teungku Muhammad Daud Beureuh accepted President Soekarno's promise that if Indonesia get independence then Aceh will become Islamic Country [30]. President Soekarno sent Aceh Mujahidin to free Indonesia from The Dutch attack. But in reality, President Soekarno who was Nationalist Communist did not fulfill that promise even he led Indonesia with anti-God communism which is very hated by Tengku Muhammad Daud Beureuh [31].

Injustice relation between central and local government so far also had caused disappointment and resentment among Aceh society. The unjust treatment by central government until now had gave broad effect to political life in Serambi Mekkah. Injustice had caused Aceh is left behind in all sectors. The life which cannot be normal make Aceh people feel anxious, scare, and worry because there are so many kidnapping, murdering, torturing, arresting and shooting. The social and cultural life of Aceh people not develop, even there is no space for local cultures to grow. People do not brave to self-express even though in the life of group. Even though the label Special Region still inherent, but there is almost no role anymore that religious and custom leaders can play. As a result, Aceh in 
New Order always in the situation of prolonged chaos, conflict and disaster.

That history cause the lack of nationalism among Aceh people particularly Southwest Aceh people, so if there is no revitalization effort then it will endanger the life in society, particularly in the life of state and nation. The government post conflict continually do revitalization effort by means of socialization to return the spirit of unity (nationalism) in society [18].

The nationalism values which are socialized to society are the values which are suited with culture in the life of Southwest Aceh people and can revive nationalism spirit which had been faded away. The following are nationalism values socialized in the effort to revitalize nationalism among Southwest Aceh people:

- The value of willingness to sacrifice, this value is soul or spirit of Indonesian nation in facing challenge both from outside and inside.

- The value of unity, this value means that diversity is united into a whole. Various kinds of religion, tribe, and language are potentially trigger violence.

- The value of mutual respect, as civilized nation, Indonesian nation since long time had built relation with another nation based on spirit of mutual respect.

- The value of cooperation value, this value is activity done by Indonesian nation in daily life who like to cooperate based on spirit of familiarity.

- The value of being proud to be Indonesian nation, this value is very needed in preserving Unitary State of Republic of Indonesia. This feeling of proud should grow naturally and do not be compelled [24].

Those nationalism values are socialized in Southwest Aceh Regency, started from governmental institution, family, school and community. This effort is continually done by Southwest Aceh government in order that nationalism still maintained and society life always in the frame of Unitary State of Republic of Indonesia.

\section{CONCLUSION}

Based on the finding result which had been explained regarding revitalization of nationalism values among Southwest Aceh people post conflict, Southwest Aceh government had done revitalization effort for people in order to revive nationalism values among Southwest Aceh people post conflict. That effort had been done through several ways, among other by doing socialization in family, school and society. The form of socialization is adjusted with situation and condition of Southwest Aceh people in order that socialization is successfully done.

It need government and community effort through formal and informal institution to do socialization toward Southwest Aceh people which aims to strengthened their nationalism which begin faded away. This effort should be done immediately in order to maintain the peace which has been realized through MoU Helsingki and there is no more conflict unrest in Aceh.

\section{REFERENCES}

[1] F.R. Kluckhohn, and F.L. Strodtbeck, Variations in Value Orientation, Wesport Conn: Greenwood Press, 1961.

[2] J.W. Grube, M. Daniel, M. Mayton, and B.R. Sandra, "Inducing Change in Values, Attitudes, and Behaviors: Belief System Theory and The Method of Values Self-Confrontation", Jurnal of Social Issues, vol. 50, pp. 153-174, 1994.

[3] Y.Q. Zakiah, and A. Rusdiana, Pendidikan Nilai: Kajian Teori dan Praktik di Sekolah, Bandung: Pustaka Setia. 2014.

[4] W. Bilsky, and S.H. Schwartz, "Values and Personality", European Journal of Personality, vol. 8, pp. 163-181, 1994

[5] Budiyono. Nilai-nilai Kepribadian dan Perjuangan Bangsa Indonesia, Bandung: Alfabeta, 2007.

[6] S. Sauri, and A. Hufad, Ilmu dan Aplikasi Pendidikan Bagian 3: Pendidikan Nilai, Bandung: Impherial Bhakti Utama, 2007.

[7] A.W. Kamakura, P. Novak, and P. Thomas, "Value-System Segmentation: Exploring The Meaning of Lov", Journal of Consumer Research, vol. 19, pp. 119-132, June 1992.

[8] S.H. Schwartz, and W. Bilsky, "Toward a Universal Psychological Structure of Human Values", Journal of Personality and Social Psychology, vol. 53, no. 3, pp. 550-562, 1987.

[9] R.L. Kenney, "Value-focused Thingking: Identifying Decision Opportunities and Creating Alternatives", European Journal of Operational Research, vol. 92, pp. 573-549, 1996.

[10] R.R. Roe, and P. Ester, "Values and Work Emperical Findings and Theoretical Perspective", Appliedd Psychology: An International Review, vol. 48, no. 1, pp. 1-21, 1999.

[11] L.T.D. Quyen, and N.M. Zaharim, "The relationship between Frienship Characteristic, Etnic Identity and Value System of Youth From Ethnic Minority Group In Vietnam: A Conceptual Framework for Research", International Journal of Humanities and Social Science, vol. 2, no. 23, pp. 133-139, Desember 2012.

[12] S.H. Schwartz, "Basic Human Values, Universals in the Content and Structure of Values: Theoretical Advances and Empirical Tests in 20 Countries", Advences in Experimental Social Psychology, vol. 25, pp. 165, 1992.

[13] M. Rokeach, and J.B.R. Sandra "Stability and Change in American Value Priorities, 1986-1981”, American Psychologist, vol. 44, pp. 775 784, May 1989.

[14] B. Maftuh, Pendidikan Resolusi Konflik: Membangun Generasi Muda yang Mampu Menyelesaikan Konfik Secara Damai, Bandung: Universitas Pendidikan Indonesia, 2008

[15] N. Webster, New Twentieth Century Dictionary, 2nd ed, 1966.

[16] L. Harbom, and P. Wallensteen, "Armed Conflict" Journal of Peace Research, vol. 44, no. 5, pp. 623-634, 2007.

[17] H. Ritter, Dictionary of Concepts in History, New York: Greenwood Press, 1986.

[18] H. Kohn, Nasionalisme: Arti dan Sejarahnya, terjemahan Sumantri Mertodipura, Jakarta: Erlangga, 1984.

[19] N. Notosusanto, Sejarah Nasionalisme Indonesia Jilid III, Jakarta: New Aqua Press, 1979.

[20] P. Ahlerup, and G. Hansson, "Nationalism and government effectiveness", Journal of Comparative Economics, vol. 39, pp. 431451,2011

[21] A.D. Smith, Theories of Nasionalism, New York: Harper and Row, 1972.

[22] Suprapto, Sosiologi dan Antropologi Untuk SMA, Bandung: Armico, 1987.

[23] Lemhanas. Pendidikan Kewarganegaraan di Perguruan Tinggi, Jakarta: PT. Gramedia, 2000. 
[24] M. Djojomartono, Jiwa Semangat dan Nilai-Nilai Perjuangan Bangsa Indonesia, Semarang: IKIP Press, 1989.

[25] H. Darmadi, Metode Penelitian Pendidikan dan Sosial: Teori, Konsep Dasar dan Implementasi, Bandung: Alfabeta, 2014.

[26] W.J. Creswell, Research Design: Pendekatan Kualitatif, Kuantitatif dan Mixed, Yogyakarta: Pustaka Pelajar, 2010.

[27] Sugiyono, Metode Penelitian Pendidikan, Bandung: Alfabeta, 2012.

[28] M.T. Pabundu, Metode Penelitian Geografi, Jakarta: Bumi Aksara, 2005 .
[29] C.A. Alwasilah, Pokoknya Kualitatif: Dasar-Dasar Merancang dan Melakukan Penelitian Kualitatif, Jakarta: Pustaka Jaya, 2002.

[30] M. Maulana, Pengaruh Konflik Politik Terhadap Sosioreligi Masyarakat Aceh Barat, Banda Aceh: Universitas Syiah Kuala, 2001

[31] H.Y. Adan, Teungku Muhammad Daud Beureu-eh dan Perjuangan Pemberontakan di Aceh, Banda Aceh: Adnin Foundation Aceh, ArRaniry Press, 2007. 